\title{
Memory, Individuals, and the Past in Averroes's Psychology
}

\section{DEBORAH BLACK}

University of Toronto

Despite the resurgence of interest in the medieval conception of memory among scholars working in a wide variety of disciplines within medieval studies, little attention has been paid in recent times to the conception of memory found in the psychological writings of medieval philosophers, especially those from the Arabic tradition. ${ }^{1}$ Scholars interested in this Arabic material have had to rely on outdated studies of the internal senses in general, many of which were focused solely on the classificatory schemes and cerebral localization of these faculties to the neglect of their interest

Earlier versions of this article were presented at the Twenty-eighth International Congress on Medieval Studies, Kalamazoo, Michigan, May 8, 1993, and in the Bradley Lecture Series at Boston College, November 5, 1993. I am grateful to Muhsin Mahdi of Harvard University for his helpful comments on the paper as part of the Bradley Lecture Series.

1. Most work on medieval conceptions of memory has been undertaken by scholars of Western medieval literature or history; some are focused on memory, whereas others treat the internal senses as a whole. One of the oldest such studies is Murray Wright Bundy, The Theory of Imagination in Classical and Mediaeval Thought, University of Illinois Studies in Language and Literature, vol. 12, nos. 2-3 (Urbana: University of Illinois Press, 1928); Averroes is discussed on pp. 185-86. Arabic authors are not considered by Frances Yates in her classic work, The Art of Memory (Chicago: University of Chicago Press, 1966), but they are mentioned briefly as background to Western authors in Mary Carruthers's more recent The Book of Memory: A Study of Memory in Medieval Culture (Cambridge: Cambridge University Press, 1990). By the same token, Nicholas Steneck's "The Problem of the Internal Senses in the Fourteenth Century," Ph.D. thesis, University of Wisconsin, Madison, 1970, considers Arabic authors only in reference to their use by Latin authors. Averroes does receive an entire chapter in Janet Coleman's Ancient and Medieval Memories: Studies in the Reconstruction of the Past (Cambridge: Cambridge University Press, 1992), pp. 401-15, but the treatment is solely from the perspective of the Latin translation, and no attempt is made to situate Averroes's views on memory in the context of his overall philosophy nor in the Arabic philosophical tradition as a whole. By far the best and most philosophical consideration of memory and the other internal senses in Averroes occurs in Michael Blaustein, "Averroes on the Imagination and the Intellect," Ph.D. thesis, Harvard University, Cambridge, Mass., 1985, although my interpretation differs in several important respects. 
for medieval cognitive theory and epistemology. ${ }^{2}$ The present study attempts to remedy this lacuna by examining the theory of memory presented by Averroes in his psychological writings, especially his early Epitome of the "Parva naturalia." I hope to show that Averroes's account of memory is more complex than has often been assumed and that he accords to memory a central place within any complete act of sense cognition. ${ }^{4}$ I begin by examining the place of memory within Averroes's account of the internal sense faculties in order to show that he conceives of memory as a perceptual faculty, not merely a retentive one. Memory is not the faculty whereby we retain past perceptions or are aware of the past as past but rather the faculty by which we grasp the individual as such. ${ }^{5}$ This claim will be substantiated through a consideration of the two basic activities of

2. The study of the classificatory schemes of the internal senses in general is indebted to the pioneering and almost single-handed efforts of $\mathrm{H}$. A. Wolfson, "The Internal Senses in Latin, Arabic, and Hebrew Philosophical Texts," "Isaac Israeli on the Internal Senses," "Notes on Isaac Israeli's Internal Senses," and "Maimonides on the Internal Senses," all reprinted in H. A. Wolfson, Studies in the History and Philosophy of Religion, 2 vols., ed. I. Twersky and G. H. Williams (Cambridge, Mass.: Harvard University Press, 1979), vol. 1, pp. 250-370. Also relevant to Averroes is H. Gätje, "Die 'inneren Sinne' bei Averroes," Zeitschrift der deutschen morgenländischen Gesellschaft 115 (1965): 255-93. The notes to Fazlur Rahman's translation of the psychology of Avicenna's Najãh, Avicenna's Psychology (Oxford, 1952; Westport, Conn.: Hyperion, 1981), pp. 77-83, also contain helpful discussions of the internal sense tradition as a whole.

3. The following abbreviations are used for Averroes's works:

EPN: Epitome of the "Parva naturalia" (Talkhìs kitäbal-hiss wa-al-mahsūs -1170), ed. H.

A. Blumberg (Cambridge, Mass: Mediaeval Academy of America, 1972); medieval Latin translations in A. L. Shields and H. A. Blumberg, eds., Compendia librorum Aristotelis qui Parva naturalia vocantur (Cambridge, Mass.: Mediaeval Academy of America, 1949). References are given first to the Arabic text, preceded by the siglum $\mathrm{A}$, then to the Latin, preceded by the siglum $\mathrm{L}$. There are in fact two Latin versions, the vulgata and the parisiana, the former of which is more faithful to the Arabic original. Unless otherwise indicated, all references are to the vulgata. There is also an English translation by Blumberg, Epitome of "Parva naturalia" (Cambridge, Mass.: Mediaeval Academy of America, 1961), which I have consulted; however, all translations in the text and notes are my own.

EDA:Epitome of the "De anima" (Talkhiș kitäbal-nafs—ca. 1159, but twice revised), ed. A.

F. Al-Ahwani (Cairo: Maktabah al-Nahḍah al-Miṣriyah, 1950). All translations are my own.

GCDA: Great Commentary on the "De anima" (Commentarium magnum in Aristotelis De anima libros—ca. 1190), ed. F. S. Crawford (Cambridge, Mass.: Mediaeval Academy of America, 1953). References are given to book and comment numbers, followed by the page and line numbers in Crawford's edition. All translations are my own.

4. By "complete" here I mean the grasping of a sensible particular as an integral whole accompanied by all or most of its relevant proper, common, and incidental sensible qualities. For example, Zayd, a red apple, and a black cat would count as complete perceptual acts, but seeing red or black, hearing a loud sound, or seeing something moving would not.

5. A preliminary terminological note is in order here. In his psychological writings, particularly the $E P N$, Averroes (along with most of his commentators) is not always careful to differentiate between the faculty of memory as a distinct internal 
the internal senses that Averroes associates with the use of the memorative faculty, analysis or abstraction (al-tah̆ll/divisio) and synthesis or composition (al-tartib/compositio). Moreover, I argue that my interpretation of Averroist memory as a perceptual faculty can be further supported by analogy with Averroes's account of the parallel activities in the intellect. Finally, I suggest that while Averroes's view of memory is a plausible one in its own right, his account is not without its ambiguities, particularly in the light of his understanding of the metaphysical status of individuals.

\section{MEMORY'S PLACE AMONG THE POWERS OF THE SOUL}

Averroes's general purpose in the De memoria chapter ${ }^{6}$ of the Epitome of the "Parva naturalia" is to establish the existence of a special memorative faculty, closely tied to imagination in its scope, yet locally and functionally distinct from it. ${ }^{7}$ Since this in itself represents a move away from Aristotle toward the more rigid demarcation of faculties characteristic of the internal sense tradition, it will be useful to begin with a few general remarks on that tradition, especially as it culminates in Avicenna.

All of Avicenna's philosophical discussions of the internal senses present a fivefold classification of faculties in which the distinction between perceptual and retentive faculties plays a pivotal role. ${ }^{8}$ The internal senses thus include two perceptual-retentive pairs: (1) the common sense (al-hiss

sense power and the activities of retaining, remembering, recollecting, and so on in which this faculty is involved. Al-dhikr in Arabic is used to mean both "memory" as a faculty and "remembering" as an activity. The present discussion is concerned with the determination of the nature and function of the faculty of memory in Averroes's cognitive psychology, and it is to this problem that its conclusion pertains. Although it is only by examining the various activities in which the memorative faculty is involved-remembering (al-dhikr/rememoratio), retention (al-hifz/conservatio), and recollection (al-tadhakkur/investigare per rememorationem or reminiscentia in the parisiana) - that the cognitive function of the faculty itself is to be determined, it becomes clear in what follows that the memorative faculty cannot accomplish any of these activities without operating in concert with a number of other internal sense powers.

6. Averroes treats the Parva naturalia as a single work, divided into individual treatises or books. He tells us (EPN, A2-3) that the only books known to him at the time of composing his epitome were De sensu et sensato (bk. 1); De memoria, De somno, and De insomniis and De divinatione (chaps. 1, 2, and 3-comprising both the De insomniis and De divinatione-of bk. 2); and the De longitudine et brevitate vitae (bk 3).

7. By "locally distinct" I refer to the standard physiological component of the internal sense tradition, which locates each faculty in a specific ventricle of the brain.

8. The principal texts are Al-Najāh ed. M. T. Danishpazhuh (Tehran: Danishgah Tehran, 1985), pp. 327-30, 344-49; English translation in Rahman, Avicenna's Psychology, pp. 30-31, 38-40; and Al-Shifă': Al-Nafs, ed. F. Rahman, Avicenna's "De anima," Being the Psychological Part of Kitab al-Shifá, (Oxford: Oxford University 
al-mushtarak), which perceives the proper and common sensible forms conveyed by the external senses, and the formative imagination (alkhayal/al-mușawwirah), which retains these forms; and (2) the estimative faculty $(a l-w a h m)$, which perceives what Avicenna calls nonsensible "intentions" $(m a \bar{a} n \bar{l})$, and the memory (al-dhikr), which retains those intentions. Intentions for Avicenna are principally illustrated by affective properties such as fear, hostility, and love, but they also include a number of other properties, among them Aristotelian incidental perceptions such as "the yellow is honey and sweet." Avicenna also posits a fifth faculty, the compositive imagination (al-mutakhayyilah), which combines and divides the forms and intentions perceived and retained by the other faculties. This faculty, however, has two aspects in humans, for when it is directed by the rational soul it is properly called the cogitative (al-mufakkirah/al-fikr), or sometimes the discriminative (al-mumayyizah), faculty.

The details of this Avicennian scheme are complex, and they are not all adopted by Averroes. But for our present purposes two related points are of note. The first is that memory is, for Avicenna, explicitly and only a retentive faculty: it merely preserves the intentions that the estimative faculty had previously grasped. The second is that although Averroes accepts the terminology of "intentions," he implicitly eliminates the estimative faculty in all of his writings, eventually rejecting it outright in the Incoherence of "The Incoherence." 10 So memory cannot continue to play the exact same retentive role that it was assigned by Avicenna. The situation is further complicated by Averroes's consistent treatment of the cogitative faculty as a human internal sense power in its own right, despite the elimination of animal compositive imagination. Thus, Averroes ends up with a fourfold schema of internal sense powers within the human soul (which he attributes to Aristotle himself): the common sense, the imagination, the cogitative faculty, and memory. ${ }^{11}$ If one sees the cogitative faculty in Averroes as

Press, 1959), pp. 43-45, 58-61, 163-69; medieval Latin translation, S. Van Riet, ed., Avicenna Latinus: Liber de anima, seu sextus de naturalibus, 2 vols. (Louvain: Peeters, 1968; Leiden: Brill, 1972), vol. 1, pp. 85-90, 114-20; vol. 2, pp. 1-11. For a consideration of the estimative faculty in Avicenna and the Averroist and Ghazalian critiques, see D. L. Black, "Estimation (Wahm) in Avicenna: The Logical and Psychological Dimensions," Dialogue 32 (1993): 219-58.

9. See Shifa': De anima 4.1, p. 166; Liber de anima, vol. 2, p. 7.

10. See Tahäfut al-Tahäfut (Incoherence of "The Incoherence"-ca. 1180), ed. M. Bouyges (Beirut: Imprimerie Catholique, 1930), pp. 543-53; English translation by S. Van Den Bergh, Averroes' "Tahäfut al-Tahāfut," 2 vols. (Cambridge: E. J. Gibb Memorial Trust, 1954), vol. 1, pp. 333-41. Blumberg's translation of the EPN obscures Averroes's implicit repudiation of a distinct estimative faculty even in this early work. Although Averroes once refers to wahm as Avicenna's term for an animal ability that has no special name of its own (see $\mathrm{n}$. 21 below), he never includes such a faculty in his own account of memory. Rather, he refers throughout to the "discriminative" (al-mumayyizah) faculty, that is, the purely human faculty equivalent to cogitation, which Blumberg misleadingly translates as "estimative."

11. See GCDA 3.6, pp. 415.68-416.79. 
simply a substitute for the estimative in Avicenna, it might remain possible for Averroes to preserve memory as nothing but a retentive capacity roughly on a par with Avicennian memory. This has been the traditional assumption among all of Averroes's readers since the Latin middle ages; it is this reading that I challenge in what follows.

In keeping with the general thrust of the internal sense tradition, then, Averroes treats memory as a distinct faculty with its own special organ, the rear ventricle of the brain. This view of memory is in turn accompanied by a radical reworking of the original Aristotelian arguments for the association of memory and imagination based on the perception of time. In his own De memoria, Aristotle argues that memory must be a function of imagination because memory involves the perception or consciousness of time (aisthesis chronou), that is, an awareness that what one is remembering had been perceived before (prosaisthanesthai). ${ }^{12}$ Averroes cannot, of course, reasonably detach the notion of memory entirely from the notion of the past, so he begins his discussion by dividing "things perceived by us" (al-

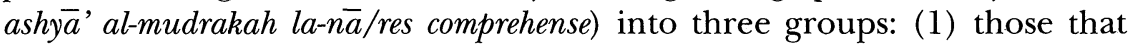
exist "in the now and the present time, like the perceptions of sensation"; (2) those "whose existence is anticipated in future time, namely, things supposed [al-umūr al-maznunnah]"; and (3) "those which were perceived in past time."13 But the division itself is carefully framed only in terms of the temporal existence of the perceived objects and the time of their perception, that is, whether it occurred or occurs in past, present, or future time. ${ }^{14}$ No awareness of time itself is actually attributed to memory; instead, Averroes merely asserts the rather obvious point, "People only remember something with which they were acquainted before, in past time." 15

But if a memory is not of the past as past, then with what is it concerned as its cognitive object, and why will it need to be differentiated from imagina-

\section{De mem. 1 (449b24-50a23).}

13. EPN, A36/L47; cf. De mem. 1 (449b24-29).

14. These points are clearer in the Arabic original than in either of the two Latin versions, although the vulgata is, here as elsewhere, more accurate than the parisiana. It is also important to note that at this point in the argument Averroes does not assign activities to specific faculties, as both of the Latin versions imply. He merely points out that present objects are "like what is perceived by the senses," whereas memory is concerned with things past. As to anticipations of the future, Averroes refers to them as "things supposed" (al-umūr al-maznūnah); they are not assigned to any "estimative faculty," as might be supposed from the Latin translators' use of res existimabliles (vulgata) and virtus estimativa (parisiana).

15. EPN, A36/L47. It is perhaps worth noting here that like all medieval authors in the Aristotelian tradition, Averroes confines the notion of memory proper to the realm of sensible particulars, following Aristotle's remarks at De mem. 1 (449b30-450a14) that memory belongs only incidentally to the thinking or rational part of the soul. Questions about habitual memory and the retention of previously learned knowledge (e.g., my remembering the Pythagorean theorem), which are central to contemporary discussions of memory, are considered by medieval authors in their treatments of the intellectual faculties. 
tion? Averroes admits that memory, imagination, and sensation all share a concern with "particular, individual, things," which are "definite in quantity." Memory-objects must, therefore, be "sensible and imaginable," and imagination is a necessary condition for the occurrence of memory; yet "even if every act of remembering and every recollection only takes place when accompanied by imagination, the notion of memory is different from the notion of imagination, and the activity ( fi $^{\prime} l /$ actio) of these two faculties is different." This latter claim is then supported by the most basic of Aristotelian principles for distinguishing powers and activities, namely, the recognition of a distinction between their cognitive objects: "The activities of the two faculties are different because the activity of the faculty of memory is only to make present the intention (ma'na /intentio) of the imagined thing after its loss, and to judge of it now that this is the intention which was sensed and imagined." 16

Averroes here introduces the technical term "intention" (ma'na $\bar{a}$ ) to denominate the distinguishing feature of the object of memory that will replace the Aristotelian connection between memory and the awareness of past time. ${ }^{17}$ Although the association between memory and intentions is found in Avicenna, as I have already indicated, it is noteworthy that Averroes does not say here that memory simply retains intentions, but rather that it involves both a new presentation and a new judgment of an intention as pertaining to some previously imagined object. Unfortunately, Averroes does not offer any definition of "intention" in this initial introduction of the term, but its meaning begins to emerge in his subsequent analysis of the elements that make up the complex activities of retaining and remembering, on which the need for a special faculty of memory is ultimately based.

Averroes argues that four distinct components can be discerned in the act of remembering: (1) the image (al-khayal/ymago), (2) its intention (ma'na al-khayall/intentio illius ymaginis), (3) the presenting of the intention (ihd̄ar dhalika al-ma'nā/facere illam intentionem esse presentem), and (4) the judgment of identity between the intention of the image and the past

16. EPN, A38/L49-51 (emphasis added). Averroes is somewhat careless in this initial description of memory since he appears to attribute both the presentation of the intention and the judgment of its identity to a past percept to memory. In the account that follows, the judgment is consistently attributed not to the faculty of memory itself but to the cogitative faculty.

17. The technical term ma'n $\bar{a}$ poses certain difficulties because it is used equivocally throughout the EPN. On the one hand, it serves here, as in all of Averroes's psychological writings, as the general term for any cognitive object insofar as it is comprehended, whether by the external or internal senses or by the intellect. In this way it refers to the "spiritual" or "intentional" being of a known object. Under this broad usage, any of the sensible forms perceived by any of the internal senses can be labeled "intentions," as can intelligible concepts. On the other hand, in the context of discussions of memory, "intention" is used as a technical term for the object of the memorative faculty. In this special sense, intentions are to be contrasted with images or forms. For discussion of the different notions of intentionality in Averroes, see Blaustein, Averroes on Imagination and Intellect, pp. 40-58, 86-87. 


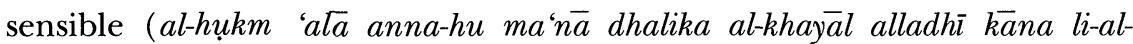
mahsūs al-mutaqaddam/iudicare eam esse intentionem illius ymaginis que prius sentiebatur). From this analysis Averroes proceeds to argue that three distinct faculties must be involved, two to account for the perception of the two aspects of the memory-object and one to account for the judgment of identity. 18 That is, since an image is a distinct perceptual object from an intention, the image and the intention must be perceived by different faculties, and a third faculty must be posited to account for their ability to be recombined. Imagination (or formation) ${ }^{19}$ is the presenter and percipient of the image as such; memory is the percipient of the intention (either continuously when retentive or intermittently when memorative);20 and the cogitative faculty, under the influence of the intellect, is compositive of the image and intention and the judge of the identity between this composite and some past perceptual object. ${ }^{21}$ Thus, Averroes argues, it is clear that memory and imagination must be distinct both in quiddity and in subject (bi-al-māhiyah wa-al-mawd $\bar{u}$ 'ah /in definitione et subiecto), ${ }^{22}$ although they act in concert in a wide variety of perceptual activities. 23

Averroes's argument for the distinction between memory and imagina-

18. Averroes does not explain why his initial fourfold analysis resolves into an argument for only three faculties, but it is implicitly because the perception and presentation of an object are taken to be functions of the same faculty. Presumably Averroes explicitly mentions the presentation of the intention, but not of the image, simply because his focus is on memory proper rather than on simple imagination.

19. Throughout the text Averroes usually prefers the term al-musawwirah, "formative faculty," to the term al-mutakhayyilah, "imaginative faculty," although the latter is used occasionally. The Latin translation almost always has ymaginativa, whatever the underlying Arabic.

20. Retention (hifz/conservatio) and remembering (dhikr/rememoratio) are distinguished by Averroes as the acts of continuous versus intermittent retention. See $E P N$, A37/L48-49.

21. "As for the judgment ... in a human being it belongs to the intellect, for in a human being [intellect] is the judge by way of affirmation and negation. And in animals that have memory, it is something like the intellect, because this power is in humans through cogitation and reflection, and for this reason they can recollect. And as for the rest of the animals, it is nature, and for this reason animals remember but do not recollect. And in animals this faculty does not have a name, and it is what Avicenna calls the estimative [faculty]. And through this power animals naturally flee what is harmful, even if they have never sensed it before" (EPN, A39/L52).

22. That is, their essential perceptual activities or functions are distinct, and therefore they require distinct material substrates within the brain.

23. EPN, A39-40/L51-55. It should be noted throughout this initial discussion that my use of the term "memory-object" reflects Averroes's own ambiguous use of the term dhikr to mean both the faculty of memory and the act of remembering (see n. 5 above). Averroes is ultimately arguing that the faculty of memory has a distinct cognitive object - that is, a distinct aspect of the extramental thing-that requires its differentiation from the faculty of imagination. But he reaches this position by analyzing the act of remembering and arguing that its object involves more than can be explained by imagination alone. Thus, both the complex object of the act of remembering and the specific aspect of that object, which the faculty of memory grasps, are "memory-objects" for Averroes. 
tion thus rests on the assumption that an intention is a distinct cognitive object from an image, a point that he attempts to establish by offering an analysis of memory-objects in terms of their formal and material components. In this analysis, every memory-object involves a material component or substratum, "which holds the rank of the subject, namely, the outline and shape," and this is provided by the image; but a memory-object also involves a formal component, and this is provided by the intention that accompanies the shape or image. This composition of image and intention in the remembered object in turn reflects the fact that the external thing is itself a composite of these two elements, that is, of an external outline or shape and an individual intention. ${ }^{24}$ Initially we might be tempted to take such a form-matter analysis to indicate an isomorphism between the ontological constituents of the external thing and the components of the memoryimage that represents it, with the image corresponding to the matter and the intention to the form of the particular hylemorphic composite. ${ }^{25} \mathrm{But}$ it is clear from Averroes's subsequent explanation of this composition that he is not claiming that the form of a material thing yields its intention and the matter its image. ${ }^{26}$ Rather, when analyzed in its own terms, the formal and material components within the memory-object reveal a composition of intention and image, and something corresponding to these perceptual components must in turn be present in and conveyed by the external thing. But the correspondence need not be a mere copying: what is a formal component in the memory-image viewed in its own right need not be the formal component of the extramental thing whose memory-image it is.

To explain this form-matter analysis and its bearing on the distinction between images and intentions, Averroes now provides the reader with an example of the distinction. The illustration is clearly derived from Aristotle's distinction, at De memoria 450b11-451a14, between an image (phantasma) viewed as an object of consideration (theōrema) in its own right and that same image considered as an eikōn-portrait or copy-of something other than itself. ${ }^{27}$ For Averroes, however, the image's role as eikon $n$ becomes

24. EPN, A40/L54: "This is because the individual outside the soul [al-shakhs khärij al-nafs/individuum enim extra animam], since it is composite [ murakkaban/compositum], happens to be in the soul in this manner."

25. As Coleman does in Ancient and Medieval Memories, p. 405.

26. Averroes's language also makes this unlikely because the material component of the memory-image is labeled its "shape" (al-shakl/figura), that is, its physical

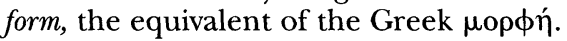

27. See especially De mem. 1 (450b21-27), translated by Richard Sorabji, Aristotle on Memory (Providence, R.I.: Brown University Press, 1992), p. 51: "For the figure drawn on a panel is both a figure and a copy, and while being one and the same, it is both, even though the being of the two is not the same. And one can contemplate it both as a figure and as a copy. In the same way one must also conceive the image in us to be something in its own right and to be of another thing. In so far, then, as it is something in its own right, it is an object of contemplation or an image. But in so far as it is of another thing, it is a sort of copy and a reminder." All translations of the De memoria are taken from Sorabji. 
transferred to the intention. Hence the property of being an eikon ceases to be a mere relative or referential aspect of the image itself and becomes instead a distinct cognitive object in its own right: 28

For that which the imaginative faculty perceives of an ostensible individual Zayd (min shakhs Zaydin al-mushär ilay-hi/de subiecto) ${ }^{29}$ is only what the painter describes of him in that which retains, ${ }^{30}$ whereas that which the memorative faculty perceives is only the intention of this description. And for this reason, the intention in the memorative faculty is more spiritual than it is in the imaginative faculty. ${ }^{31}$

The allusion to the painter's description of Zayd is clearly derived from Aristotle's use of the distinction between pictures and portraits or copies to solve the dilemma of what makes a memory-image unique. A mere image involves only the depiction of the external features of the object, of its proper and common sensible properties such as color, shape, and so on. So the intention must represent some element within the ostensible individual that is not encompassed by its image, and that would seem to leave only its underlying individuality. Thus the perception of an intention for Averroes would seem to entail the recognition of an individual precisely insofar as it is an individual.

There is one other important point in the preceding argument for the distinction between imagination and memory. While the distinction turns

28. The basis for Averroes's argument is clearly the De mem. passage, but his use of the argument is squarely within the internal sense tradition and in many ways quite opposed to Aristotle's own perspective here, insofar as Averroes multiplies faculties and cognitive objects. The temporal focus of the Aristotelian text in contrast to the purely atemporal and aspectual analysis of Averroes is also noteworthy. In Aristotle, the eikon-phantasma contrast arises from an aporia directly linked to the temporality of memory: if memory is of the past as past, but all forms of perception must, qua actual, be of what is present, then how can one remember what is not present? Aristotle thus faces the problem of whether the object of memory is properly the present affection or the original percept that generated the memory. But once the temporal element has been erased from Averroes's account, this aporia is no longer at issue: the intention as such is what one remembers, and it makes no difference whether it is present, past, or future.

29. Al-mushār ilay-hi, literally, "the thing indicated/pointed to," is the Arabic translation for the Greek $\tau$ ó $\delta \varepsilon \tau \imath$, "this something," and it is standardly rendered as "ostensible" or "denotable." The Latin version paraphrases rather than translates this phrase as "subject."

30. I have rendered the active participle, al-hâfiz, by the vague phrase "that which retains" to leave open the possibility that Averroes is referring to the percipient subject as a whole rather than to the retentive faculty. This would resolve the apparent anomaly of calling the imagination the retentive faculty, for although it is true that imagination is retentive of images, this label is traditionally reserved for the faculty of memory. Moreover, such an anomaly would obscure Averroes's ultimate intention in the passage cited, which is to prove that while remembering and retention are two aspects of a single memorative faculty, the faculties of imagination and memory are distinct in both subject and quiddity.

31. EPN, A41/L55-56. 
on the recognition that the image and the intention correspond to two really distinct aspects or components of the remembered object and its external counterpart, they form a unity of some sort, and both the image and the intention are assumed to be represented in some way in the faculties of imagination and memory alike. The intention of the thing is described by Averroes as being present in the imaginative faculty, as well as in the memory, and in what follows I hope to show why it must be present, given the abstractive process that Averroes attributes to the sequence of internal senses as a whole. Still, despite the presence of intentions in both faculties, Averroes also tells us here that memory-or rather, the intention in the memory-is more spiritual, that is, more abstract, than it is in the imagination. And the reason for this seems to be that it is only in the memorative faculty that the intention itself actually comes to be perceived. ${ }^{32}$

\section{MEMORY, ANALYSIS, AND THE GRADES OF SENSIBLE ABSTRACTION}

That memory is the primary locus of the actual perception of the intention emerges quite clearly from Averroes's ensuing discussion of the first of the two cognitive activities in which the input of the memorative faculty is implied, sensible analysis or division (tahlil /tafșil /divisio). "Analysis" is Averroes's term for the process whereby each of the internal senses performs some act of sensible abstraction. Once again, the notion of abstraction as intrinsic to sense perception, as well as to intellectual apprehension, has Aristotelian origins, which crystallize into a more rigid doctrine in the internal sense tradition. The Aristotelian roots of this doctrine lie in the well-known claim that sensation (aisthesis) is in general "that which can receive perceptible forms without their matter," a claim that is followed immediately by the analogy of wax receiving the impression of a signet ring. ${ }^{33}$ In Avicenna's cognitive psychology this Aristotelian passage is echoed as the basis for the claim that the totality of human cognitive capacities comprises a hierarchy of abstractive powers, beginning with the external senses, proceeding through imagination and estimation, and terminating in reason or intellect: "It is likely that all perception (idra $k$ ) is simply the taking $(a k h d h)$ of the form of the perceived thing in some way; so if the perception is of a material thing, it is the taking of its form abstracted in

32. Cf. GCDA 2.63, p. 226.57-59, where Averroes says that the intention is "the very same thing that the imaginative power comprehends, but the imaginative power comprehends it conjoined to those sensibles" ("Et hec eadem est illa quam comprehendit ymaginativa, sed ymaginativa comprehendit eam coniunctam istis sensibilibus").

33. De an. 2.12 (424a17). All translations of the De anima are taken from D. W. Hamlyn, Aristotle's "De anima” Books II, III (Oxford: Clarendon Press, 1968). 
some way from the matter." 34 Given this general definition of abstraction, the internal ordering of abstractive powers is deduced by Avicenna on the basis of the relative degrees of dependence on matter within each type of perceptual act. Sensation is the least abstractive power because it depends on the material presence of the external object; imagination (al-khay $\bar{a} l){ }^{35}$ is more abstract simply because sensible forms remain in it even in the absence of the material object itself, even though these forms represent the material accidents of the object; and estimation is the most abstract of the sensible faculties because its intentions are properties that are not themselves material, although the estimation always represents them in conjunction with material forms. ${ }^{36}$ Neither the compositive imagination nor the memorative faculty is mentioned by Avicenna as occupying a special abstractive grade of its own.

Averroes follows the general contours of the Avicennian paradigm, accepting that all forms of cognition involve abstraction or analysis and that these abstractive processes can be hierarchically arranged from the most material to the most formal and abstract. But since his understanding of the distinctions among the individual apprehensive powers within the abstractive hierarchy differs from Avicenna's, his understanding of the abstractive scheme itself differs accordingly. In general terms the process of sensible analysis for Averroes encompasses the various stages involved in the perception of any sensible particular. In Averroes's own terms, "Analysis and division are only concerned with the definition of the sensible thing inasmuch as $(m \bar{a} d \bar{a} m a / d u m)$ it is sensible." 37 Averroes sketches the respective roles of each of the four internal senses in the act of analysis as follows:

This occurs by the sense first perceiving the thing outside the soul, then the formative faculty [i.e., the imagination] forming [an image] of it, then the discriminative faculty [i.e., the cogitative faculty] distinguishing the intention of this form from its description. And then the retentive faculty receives (yaqbalu/recipit) what the discriminative faculty had distinguished. ${ }^{38}$

In thus dividing the labor among the internal senses, the only activity that Averroes explicitly attributes to the cogitative faculty is that of separating or abstracting the intention from the image. In virtue of the discriminative

34. Avicenna, Shifa': De anima 2.2, p. 58; Liber de anima, vol. 1, p. 114; cf. Rahman, Avicenna's Psychology, p. 38 (for discussion of this aspect of the internal sense tradition, see pp. 96-97); Blaustein, Averroes on Imagination and Intellect, pp. 82-85.

35. This is the formative imagination (al-musawwirah), the storehouse of sensible forms, rather than the compositive imagination.

36. Avicenna, Shifá': De anima 2.2, pp. 58-61; Liber de anima, vol. 1, pp. 114-19; cf. Rahman, Avicenna's Psychology, pp. 38-40.

37. $E P N, \mathrm{~A} 41 / \mathrm{L} 56$.

38. EPN, A41-42/L56-57. 
activity of the cogitative faculty, the intention is able to be understood in isolation from its corresponding image. But here and in the remainder of the text the perception of the intention is never attributed to the cogitative faculty, whereas this is often said to be the distinctive mark of the memorative faculty. ${ }^{39}$ This faculty is said to receive the intention, not merely to store or preserve the intention as something already known. It is now my aim to show that only by attending to this point can Averroes's claim that memory is the highest and "most spiritual" of the internal sense powers, a claim that he makes in the continuation of this passage and elsewhere in his psychological writings, be given a coherent and nontrivial interpretation:

And for this reason there are five grades here. The first of them is corporeal, having many rinds, and it is the sensible form outside the soul. And the second grade is the existence of this form in the common sense, and it is the first of the spiritual grades. The third grade is its existence in the imaginative faculty, and it is more spiritual than the first. The fourth grade is its existence in the discriminative faculty, and the fifth is its existence in the memorative faculty. And this is the most spiritual of them, for memory receives (fa-inna-ha taqbalu/recipit enim) the fruit which the three [other powers] have distinguished and cleansed of its rinds. ${ }^{40}$

The fruit-rind metaphor, which is used here and recurs throughout Averroes's account of the internal senses, is meant to capture the claim that the intention of the perceived thing is distinct from its imagined shape or outline, as Averroes tells us in the first chapter of the Epitome of the "Parva naturalia, "which corresponds to Aristotle's De sensu et sensato. ${ }^{41}$ Memory is explicitly said to be the most spiritual internal sense faculty because in it alone the fruit is received, purified of all its rinds. The actual reception of this "fruit" is unique to the memorative faculty-it is not attributed to the cogitative faculty first and thereafter to the memorative faculty as a simple

39. The same basic picture of the roles of the cogitative and memorative faculties in the process of sensible abstraction is preserved in the later GCDA 2.63, pp. 225.54-226.57, where Averroes says that the cogitative faculty "separates" (distinguit) and "abstracts" (expoliat) the individual intentions from the imagined forms of the common and proper sensibles and "deposits" (reponit) them in the memory.

40. EPN, A42-43/L58-59. Cf. GCDA 3.6, pp. 415.56-416.79: "And he posits the memorative as more spiritual, then the cogitative, then the imaginative, and afterwards the sensible."

41. EPN, A33/L42: "And this is because in the human being the differences of things and their proper intentions are perceived. And these are the things which hold the rank, in the sensible thing, of the core of the fruit, whereas in the animal, only things which are external are perceived, these being that whose relation to the things is the relation of the rind to the core of the fruit," Of course, the implication of this passage-and of the cogitative faculty's role in the process of sensible abstraction-is that nonhuman animals will not only be denied the capacity for recollection but also not have memory itself in any proper sense. 
storehouse. Taken at his word, then, Averroes is claiming that only in memory is the individual grasped in its individuality. To remember something is not primarily to recognize it as a past object of perception but to comprehend it as this particular thing. I cannot remember something unless I recognize it, not as a random collection of sensible qualities, but as a determinate individual distinct from all other such individuals, or in Aristotle's terms, as an eikōn, as well as a phantasma.

\section{ABSTRACTION AND RECEPTION: ANALOGUES TO ANALYSIS IN THE INTELLECT}

Thus far, I have made my case for this interpretation of Averroes's view of memory on purely exegetical grounds: Averroes explicitly declares that memory is the highest of the internal sense faculties because of its unique role in the grasping of intentions. But it has traditionally been assumed-principally on the basis of the commonsense assumption that to distinguish $\mathrm{x}$ from $\mathrm{y}$, one must have a prior perception of both $\mathrm{x}$ and $y^{42}$ - that Averroes must hold that the cogitative faculty first grasps the intention before depositing it in the memory. Memory's claim to greater spirituality must then be interpreted in a different way, and it is easiest to assume that insofar as memory has a retentive function analogous to that of the imagination, it is likewise more spiritual than the cogitative faculty in the same way that imagination is more spiritual than sensation. Since the imagination is considered more spiritual than sensation because it is independent of the material presence of the external sensible object, by parity of reasoning memory can be seen as more spiritual than the cogitative faculty because it is able to retain an intention in the absence of the cogitative faculty's conscious consideration of that intention. ${ }^{43}$

42. Apart from common sense, there is also Aristotelian background in the discussion of sensible discrimination at De an. 3.2 (426b8-427a15). Blaustein, Averroes on Imagination and Intellect, pp. 108-9, may well have the Aristotelian background in mind since he uses Averroes's analogy between the discriminative capacities of the common sense and the cogitative faculty to support the claim that the cogitative faculty is aware of intentions.

43. Thus Blaustein, Averroes on Imagination and Intellect, p. 85, argues, "Presumably (Averroes does not say so), memory is most abstract because it retains the individual intention even after the cogitative faculty has ceased paying attention to the associated imaginative form."

Averroes's followers in the medieval Latin tradition, such as John of Jandun, also assumed that the cogitative faculty is a percipient faculty and memory simply its storehouse. See, for example, Super libros Aristotelis De anima (Venice, 1587; Frankfurt am Main: Minerva, 1966), p. 214: "Primo, quidem de ista virtute [scil. cogitativa] dicit Commentator in secundo huius, quod ipsa cognoscit intentiones, id est formas indiuiduales omnium decem praedicamentorum, ut formam indiuidualem huius hominis, secundum quod hic homo, et hanc lineam . . . et huius- 
But whatever the commonsense appeal of this claim, it does not cohere with what Averroes actually says makes memory the most spiritual of all faculties. Moreover, it is not required by the principles of Averroes's general theory of cognition nor warranted by the vocabulary that he uses to describe the respective activities of the cogitative and memorative faculties. As I have already noted, Averroes almost always describes memory as a receptive faculty and cogitation as a compositive or discriminative one. ${ }^{44}$ And in his overall account of cognition (as in its Aristotelian roots), it is the passive act of receiving a form, not the active process of abstracting it, that constitutes the act of understanding, that is, grasping the nature of the object known.

This is, of course, most evident in both Averroes's and Aristotle's accounts of the potential or material intellect, which "is of this kind by becoming all things." 45 It is the potential intellect in an Aristotelian epistemology that explains how we become affected by and aware of an intelligible object. While this should be obvious from the basic structure of Aristotle's own cognitive theory, Averroes himself several times makes explicit the links between reception, comprehension, and understanding. In comment 7 of book 3 of the Great Commentary on the "De anima," for example, when describing the preparatory functions of the internal senses in relation to intellectual understanding, Averroes explicitly gives "to receive" (recipere) as a synonym for "to comprehend" (comprehendere): "And all these [internal sense] faculties help each other to present the image of the sensible thing, so that the abstract rational power may look upon it and extract the universal intention, and afterwards receive, that is, comprehend it." 46 Similarly, in the description of the abstractive process in his commentary on De anima 3.5, Averroes distinguishes "abstraction" (abstrahere) from "reception" (recipere) and "understanding" (intelligere):

modi plura ita quod non tantum cognoscit accidentia sensibilia communia et propria, sed intentionem non sensatam, et exspoliat eam ab eis, quae fuerunt ei coniuncta de sensibilibus communibus et propriis . . . . Unde per tuam virtutem cogitatiuam tu cognoscis, quod haec anima non est idem cum hoc corpore, et hoc manifestum est. Et etiam, quod haec amicitia non est idem cum hoc colore, vel cum hac magnitudine, vel motu, vel huiusmodi, et ipsam intentionem reponit cogitatiua in virtute memoratiua, ut dicit Commentator."

44. The application of the term "reception" (qubu l/receptio) to memory also occurs in the earlier analysis in the EPN of the elements involved in memory-images. The activities of presentation ( $i h d \bar{a}$ r / facit presentari), assigned to memory and imagination, are called acts of reception, and they are contrasted with the act of composition (tarakkub/compositio) proper, assigned to the cogitative faculty: "This is because the individual outside the soul (al-shakhs khärij al-nafs/individuum extra animam), since it is composite, happens to be in the soul in this way, and the reception of the two parts from which it is composed belongs to two different faculties and the composition of the two to a third faculty" (EPN, A40/L54).

45. De an. 3.5 (430a14-15).

46. GCDA 3.7, p. 419.59-63: "Et omnes iuvant se ad presentandum ymaginem rei sensibilis, ut aspiciat eam virtus rationalis abstracta et extrahat intentionem universalem et postea recipiat eam, idest comprehendat eam." 
And it was necessary to ascribe to us these two actions of the soul, namely to receive the intelligibles and to produce them ... on account of the fact that these two actions, namely, to abstract intelligibles and to understand them, are reduced to our will. For to abstract is nothing other than to make the imagined intentions understood in actuality after they were in potency; but to understand is nothing other than to receive these intentions. ${ }^{47}$

In both these passages, reception is the cognitive activity that is proper to the potential intellect, and it is clearly distinguished from the abstractive activity of the agent intellect when it extracts the universal essence from the particular image. It is my contention, then, that Averroes intends the cogitative faculty to perform a function analogous to the function played by the agent intellect on the level of universal understanding, and the memorative faculty to be the analogue of the potential intellect. If this is the case, the cogitative faculty, at least in its discriminative capacity within the process of analysis, need not and, indeed, cannot properly be said to understand or comprehend the intention prior to conveying it to the memory, just as the agent intellect, in Averroes's noetic theory, cannot be said to know, in any standard sense of the term, the universals that it abstracts. ${ }^{48}$

\section{THE SYNTHETIC ACTIVITIES THAT INVOLVE MEMORY}

In addition to the basic activity of sensible abstraction or analysis, Averroes identifies a second cognitive activity that involves the memorative faculty, which he labels "synthesis" or "composition" (al-tartib/compositio). It is clear that the distinction between analysis and synthesis as it is used in this text serves primarily to differentiate memory's role as a special internal sense faculty, with its own proper cognitive operation in all acts of sensible abstraction, from its standard role in the explanation of the process whereby the retrieval and restoration of past perceptions is effected. Analysis pertains to

47. GCDA 3.18, p. 439.71-78: "Et fuit necesse attribuere has duas actiones anime in nobis, scilicet recipere intellectum et facere eum ... propter hoc quia hee due actiones reducte sunt ad nostram voluntatem, scilicet abstrahere intellecta et intelligere ea. Abstrahere enim nichil est aliud quam facere intentiones ymaginatas intellectas in actu postquam erant in potentia; intelligere autem nichil aliud est quam recipere has intentiones."

48. For Averroes's views on the nature of the agent intellect and its relation to the material intellect, see especially $G C D A 3.19$, pp. 440.6-443.91. For a comprehensive consideration of the role of the agent intellect in his philosophy, see $\mathrm{H}$. A. Davidson, Alfarabi, Avicenna, and Averroes on Intellect: Their Cosmologies, Theories of the Active Intellect and Theories of Human Intellect (Oxford: Oxford University Press, 1992), pp. 220-57, 315-56. 
the first of these two roles, synthesis to the second. ${ }^{49}$ This is evident from the very fact that Averroes's treatment of synthesis is developed in the section of the Epitome of the "Parva naturalia" that is devoted to recollection. ${ }^{50}$ However, synthesis is not restricted by Averroes to these more standard activities that are associated with memory. Rather, the retrieval of past perceptions through recollection is treated by Averroes as only one possible application of these synthetic activities of the internal senses. Along with remembering and recollecting, he includes the creative exercise of the imagination among the activities to which memory contributes.

Averroes's analysis of how the internal senses cooperate in the process of synthesis makes it clear why these apparently disparate activities have been grouped together as part of a consideration of the nature of memory. For according to Averroes, remembering, recollecting, and the fictional or creative uses of imagination all require the input of the same three faculties responsible for sensible abstraction-imagination, cogitation, and memory. To remember or consciously to recollect a past perception, it is necessary to recover and recombine the elements that were initially abstracted by these three faculties: imagination must re-present the description of the sensible qualities of the object to be remembered or recollected; memory must make its intention present again; and the cogitative or discriminative faculty must recombine them into a single memory image, reuniting what it had previously discriminated "since the composer is also the divider."51 Following Aristotle's views on recollection, Averroes claims that these synthetic operations of the internal senses are unique to humans since they require the influence of the rational soul, whereas the analytic activities of sensible abstraction involve only the animal soul's exercise of its own proper functions. Despite the involvement of reason, however, Averroes does not claim that it is the intellectual faculty that actually composes the images and the intention. The internal senses are clearly responsible for both the actual presentation of the individual components and their synthesis. What Averroes attributes to reason here is simply the ability to harness and consciously to direct the activities of the animal faculties. For when he explains the requisite involvement of the intellect, he mentions nothing other than the internal senses' "obedience to reason." 52 Thus neither here nor in the basic ana-

49. See EPN, A41/L56: "And therefore the action of this faculty with respect to the sensible form is either one of two actions, synthesis or analysis, such that whenever it recovers the form which it had sensed [before], then its action is synthesis."

50. EPN, A43/L59-60: "And it is clear that retention (al-hifz /retentio) is nothing but the continuity (istish $\bar{a} b /$ continuatio) of the existence of the intention of the sensible in this faculty without interruption; that forgetting is its departure [from this faculty]; remembering (al-dhikr/rememoratio) is its return after having been forgotten; and recollection (al-tadhakkur/investigatio rememorationis, [reminiscentiaparisiana]) is its recovery, and is proper to human beings."

51. EPN, A44/L60. 
lytic process of sensible abstraction does Averroes assign to the cogitative faculty any activity other than the actual combination or division of the image and intention.

As I have already noted, Averroes holds that in addition to recollection, creative imagination-or more accurately, the representation of sensible objects that the percipient herself has not actually experienced in the past-also requires the intellect's facilitation of a parallel cooperation among imagination, memory, and cogitation: "And not only does the presentation of something which had been sensed and forgotten come about from the conjoining of these faculties and their mutual cooperation, but in some people the forms of sensible things which have not been sensed before may also be presented when these faculties are conjoined, although their descriptions alone are conveyed to them."53 Averroes gives the example of someone who had never actually seen an elephant having the ability to imagine one accurately, simply based on its description. ${ }^{54}$

52. EPN, A45/L63: "And this happens only to humans, while these three faculties are united. And their unity only occurs in virtue of the rational soul, that

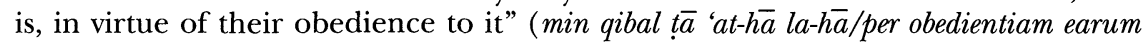
ad ipsam).

53. EPN, A45/L62. Cf. GCDA 3.33, p. 476.51-57: "For as has been shown in the De sensu et sensato, when the cogitative power cooperates with the informative and memorative powers, it is naturally able to present, from the images of things, something which it had never sensed, in accordance with the same disposition in which it would have been if it had sensed it, by assent and conceptualization. And then the intellect will judge those images by a universal judgment." The same point is made in the chapter on imagination (al-takhayyul, taken broadly in this context for the entire collection of internal sense powers) in the $E D A$, p. 60: "Moreover, we are also able through this power to compose things which we have not yet sensed, but rather, which we have only sensed singly, such as our conception of goat-stag and of ghoul, and of what is like them among the things which have no existence outside the soul, but which this power merely fabricates. And it is likely that this is one of the activities of this power which is proper to human beings. And we will explain in the De sensu et sensato the things which separate humans from the other animals in these powers, and one animal from another, as well as the things which they share in common."

54. EPN, A45/L62-63. The example is attributed to Aristotle himself, as is the entire account of certain "ancients" who could form images of things they had never seen on the basis of verbal descriptions. The example of the elephant is found earlier in Ibn Bajjah's (Avempace's) Tadbir al-mutawahhid (Governance of the Solitary), ed. M. Fakhry, in Ibn Bäjjah: Opera metaphysica (Beirut: Dār al-Nahār, 1968), p. 61, to whom Averroes is clearly indebted for many of his views on the internal senses. Perhaps the example is loosely inspired by Aristotle's discussion, at De mem. 1 (451a2-12), of people who cannot distinguish their fictional images from true memories. Averroes's attribution of this example to Aristotle may be explained by the Arabic text of the Parva naturalia, which seems to differ from the text as we know it today. On this point see S. Pines, "The Arabic Recension of Parva naturalia and the Philosophical Doctrine Concerning Veridical Dreams According to al-Risăla al-Manämiyya and Other Sources," Israel Oriental Studies 4 (1974): 104-53; Gätje, "Die 'inneren Sinne,'” pp. 264-65. 
Initially, from Averroes's allusion in this passage to simple descriptions of the object to be imagined, it might seem that there are no intentions involved here. After all, the elephant example would appear to parallel Aristotle's own example of an image that is nothing but a picture, in contrast to a portrait, copy, or likeness (eikon). But the fact that memory is implicated in the process suggests that there must be an intention involved, for Averroes has explicitly associated memory with intentions. And given his interpretation of an intention in his account of analysis, it is not only consistent but also absolutely essential that any definite, determinate image we entertain (i.e., any image that is not just a patch of color or a discrete smell or taste, etc.) must always be accompanied by some sort of intention if it is to represent an individual. If I imagine something like Averroes's elephant on the basis of someone else's description of its size, shape, color, and so on, then even if I have not experienced that thing myself I must supply some sort of intention on the basis of my own perceptions in order to meet the condition of unity required to make this description the representation of an individual thing. Only through an intention can a series of discrete images be linked together to form a single, unified sensible object.

The inclusion of memory as a faculty involved in creative imagination, as well as in remembering and recollecting, is obviously facilitated by the freeing of memory from any necessary connection with the awareness of past time. Such a move would not be intelligible-indeed, it would pose great difficulties for Averroes's cognitive psychology-were memory to be regarded as merely a retentive capacity for storing past sensible experience. For if memory were tied to the perception of the past as past, and not to the entertaining of images as representations of concrete individuals, then Averroes would be able to offer no cogent account of how veridical memories differ from the hallucinatory experiences of fictional images. That is, if memory were still tied to an awareness of the past, then its new role in the creative acts of imagination would presumably entail that every fictional, nonempirical image that I create would be represented as something that I had once experienced. But when memory is tied only to intentions, there is room left for me to supply an analogous intention to unite the new cluster of images into a concrete whole, without my thereby being deluded about the empirical character of that image as a past perception. Averroes's reinterpretation of memory does not, of course, explain how I can distinguish between veridical memories and simple acts of imaginative creativity. In fact, from the allusions to the role of the intellect in the account of synthesis, it appears that such an explanation cannot be given entirely from the side of the internal sense faculties themselves. Rather, this determination seems to demand some adjudication of and direction by the intellect. But even given the intellect's role, it remains the case that without the basic interpretation of memory's cognitive function, no explanation at all could be offered, either through the internal senses or through the intellect, about how memory could in any way be construed as an integral part of the 
creative use of imagination without thereby threatening the accuracy of memory in the representation of what is truly past.

\section{AN OBJECTION: ANALOGUES IN THE INTELLECT REVISITED}

Two possible objections might be made to my overall interpretation of the respective roles of memory and the cogitative faculty in Averroes's account of sensible cognition, both of which stem from certain disanalogies between the activities of the intellect and the internal senses:

1. The respective ranks of the agent and material intellects are the converse of the ranks of memory and cogitation within the sensible grades of abstraction; that is, the agent intellect is considered by Averroes to be nobler than the material. But if the cogitative faculty is analogous in function to the agent intellect, why is it not superior to, and hence more spiritual than, the faculty of memory, which in my interpretation is analogous to the material intellect?

2. The judgmental or combinatory function attributed to the cogitative faculty in the recollective and creative processes is one whose intellectual counterpart clearly belongs to the material, and not to the agent, intellect.

Both of these difficulties can be resolved by a careful consideration of the disparities between the respective objects and operations of sensible and intelligible cognition in Averroes's epistemology. But their resolution also brings us up against what I argue is a major philosophical impediment to Averroes's ability to reconcile memory's role in the understanding of individuals with his overall account of human knowledge.

\section{Principles of Ranking Faculties}

Averroes's principle for ordering the abstractive ranks within the internal sense faculties is never clearly spelled out, except in terms of the fruit-rind metaphor: an internal sense faculty is more abstract the fewer "rinds" it contains, and memory is at the summit of the hierarchy because in it the fruit, that is, the intention, is divested of all its rinds. ${ }^{55}$ But Averroes does

55. The actual ranking of the internal senses derives from Ibn Bājjah, Governance of the Solitary, p. 62, who also places memory at the apex of this hierarchy; unfortunately he, too, gives no rationale for the ranking. Moreover, while memory is associated with intentions in Ibn Bajjah (see p. 58), this association is not explicitly called on to explain the spirituality of memory. 
not tell us precisely what a "rind" is; given the link between the "fruit" and the intention, one would assume that the rinds comprise the various common and proper sensible qualities of the perceived object. But then it is unclear how there could be more or fewer rinds in the common sense, for example, than in the imagination. ${ }^{56}$ From his general comments on the relations between the common sense and the imaginative faculty in the Epitome of the "De anima," it is clear that Averroes holds that one faculty is more spiritual than another the further its contents are from a material substratum. Therefore, the imagination is said to be more spiritual than the common sense because its contents are derived from the traces of sensation that persist in the common sense itself-traces that thus exist in a spiritual, rather than a material, state-whereas the contents of the common sense are directly dependent on contact with external, material objects. ${ }^{57}$ While this still does little to explain the meaning of degrees of spirituality within the various sensible "rinds" themselves, when combined with Averroes's comments about memory and intentions it suggests an obvious principle for determining the relative abstractness of the internal sense faculties. Since none of these faculties reaches the complete abstraction of the universal as such, their internal ordering must be based on the degree to which they approximate the various characteristics of universal abstraction and intellectual apprehension. Thus, one internal sense power can be more abstract than another in virtue of its dependence on a prior spiritual faculty of the soul, rather than on external material things, or in virtue of its concern with the most abstract element within the sensible particular, its individual intention. 58

But when Averroes considers the principle of ranking within the intellectual soul itself, where all cognition is universal, abstract, and immaterial, that ranking can no longer be based on the degree of universality and abstraction in the cognitive act. Rather, Averroes reverts to the basic claim that the agent is always nobler than the patient: "And it has already been shown that the relation of the agent intellect to the potential intellect is in

56. Averroes also confuses matters further when he distinguishes forms that are easy for the memory to recover from those that are difficult to recover on the basis of whether or not the forms are received by the common sense "with few rinds" (EPN, A47-48/L66).

57. $E D A$, pp. 62-64: "Moreover, the affection of this power [of imagination] (infi $\bar{a} l-h \bar{a})$ does not come from the sensibles actually [existent] outside the soul, but rather, from the traces arising from the sensibles in the sensitive power, as we shall explain later. And to the extent that this is its nature, it is more spiritual .... And in general, there is in the common sense the power to retain the traces of the sensibles and preserve them. But whenever we posit that the imagination itself is only concerned with the existence of these traces remaining in the common sense after the passage of the sensibles ... so that they have in the matter of the imagination an existence more spiritual than they have in the common sense, it follows that we will imagine many things simultaneously."

58. Compare Avicenna's two principles of ranking in the texts cited at nn. 34 and 36 above. 
some way like the relation of the moving principle to the moved matter; but the agent is always nobler than the patient, and the principle nobler than the matter." 59 Now while the cogitative faculty may perform a role analogous to the agent intellect insofar as it purifies the individual intention for the memory, just as the agent intellect abstracts the universal from the particular image, it is not, strictly speaking, the act of abstraction alone that makes the agent intellect nobler than the material intellect. The agent intellect is not nobler simply in virtue of producing specific acts of knowing in the material intellect but rather because it produces those acts in the material intellect in virtue of the fact that in its own nature it is always in act. By contrast, while the cogitative faculty is an agent with respect to the extraction of intentions from images, it is not in itself always actual, and hence it is not a complete agent cause even in the process of sensible analysis. The individual intention, unlike the universal, is already actually present in the imagined form, and to this extent the use of the language of abstraction with respect to the internal senses is misleading. Thus, however helpful the analogy between the agent intellect and the cogitative faculty may be for understanding Averroes's views on the internal senses, the principle that the agent is nobler than the patient fully applies only when the agency or actuality in question is complete, and this criterion is not met in the case of the cogitative faculty.

\section{Composition and Judgment}

We have already noted that Averroes assigns both an abstractive and a combinatory role to the cogitative faculty in the respective activities of analysis and synthesis, on the grounds that "the composer is also the divider." Averroes also holds that in synthetic activities the cogitative faculty "judges" that this intention does indeed belong with this image or set of images, that is, that these sensible qualities match the physical description of this particular individual. ${ }^{60}$

59. GCDA 3.19, p. 442.58-62, referring to Aristotle's use of this principle at

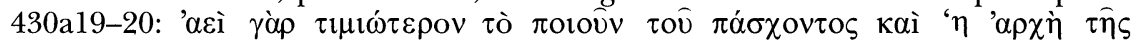

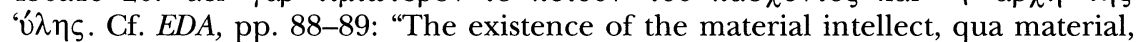
necessarily requires that there always be an intellect existent in actuality which is not material. And this is clear from the foregoing principles of physics. Moreover, everything which does not require matter in its proper activity is not material at all. For this is clear from the fact that this agent only bestows the nature of the intelligible form insofar as it is an intelligible form. And from this it is clear that this intellect, the agent intellect, is nobler than the material, and that it is existent per se as an intellect in actuality always, whether we understand it or not, and that the intelligible is in every respect in the intellect."

60 . In the texts cited at nn. 52 and 53 above, we have also seen some involvement of the intellect in these judgments, although I have argued that the intellect is not itself the combiner. It is also important to remember that the cogitative faculty by definition is a human faculty, whose operations, while material and sensible, always presuppose some interaction with the rational soul. 
Here again there is a certain analogy with the operations of the intellect, to the extent that in the Aristotelian tradition composition is generally taken to be synonymous with judgment. ${ }^{61}$ Similarly, Averroes's claim that the divider and composer must be the same reflects the fact that the terminology of composition and division is most properly used for the acts of affirmative and negative judgment. But despite these obvious parallels, Averroes does not hold that the composer and divider are one when the division in question is the intellect's act of abstracting because he is adamant that it is the material intellect, not the agent intellect, that is responsible for acts of both judgment or assent and denial or negation. This is stated forcefully in the Great Commentary on the "De anima," in which Averroes criticizes his predecessor Ibn Bajjah on precisely this point: "But Ibn Bajjah seemed to concede this proposition to be true in his Farewell Letter, 62 namely, that the power by which we make universal judgments is infinite; but he supposed this power to be the agent intellect, according to the clear intent of his language there. But this is not the case; for judgment and distinction in us are attributed only to the material intellect." 63 By parity of reasoning, one might expect that the cogitative faculty, as compositive, must, like the material intellect, be the percipient of both the simple elements that it combines, whether in memorative or in anticipatory and creative activities. ${ }^{64}$

This objection can be met most directly by the observation that if the analogy between the cogitative faculty and the material intellect as compositive powers were taken as evidence that the cogitative faculty must be the primary percipient of intentions, then by the same token it would also have to be the primary and true percipient of sensible images as well. And neither Averroes's texts nor the views of his predecessors and interpreters offer any warrant for such a claim.

61. See De an. 3.6 (430b26-32) and De int. 1 (16a10-19).

62. The work of Ibn Bajjah is the Risälah al-wada' (Epistola expeditionis), which is edited by Fakhry, Opera metaphysica, pp. 113-43. I am grateful to Richard C. Taylor of Marquette University and Thérèse-Anne Druart of the Catholic University of America for identifying the Latin reference.

63. GCDA 3.19, p. 442.46-52. Cf. GCDA 3.22, p. 457.37-44: "That is, what makes these single intelligibles to be one through composition after they had been many is the material intellect. For it distinguishes single intelligibles, composing those that are compatible (consimilia) and dividing those that are diverse. For it is necessary that the power comprehending the simples and the composites be the same, because the relation of that power to the intentions of the imagined forms should be like the relation of the common sense to the diverse sensibles."

64. In the case of Averroes's polemic against Ibn Bäjjah's claims about the role of the cogitative faculty (cited in the previous note), the problem can easily be resolved since from the context it is clear that his objection is against an individual, sensible power acting as the composer of universal forms to which its cognitive capacities do not extend. He is not concerned with the relationship between the comprehension of the simple and combination and division but with the general gap that separates the rational from the sensible soul. 
Moreover, this second disparity between the intellectual faculties and the internal senses, like the first one, can be explained by a closer examination of the differences between the cogitative faculty and the agent intellect. In the case of the intellect, Averroes's claim that the material, and not the agent, intellect is the composer of universal concepts is required in large part by the agent intellect's complete transcendence of the order of material forms. Because of that transcendence, which is based on the Aristotelian assumption that the contemplative activity of separate substances must

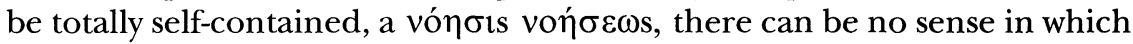
the agent intellect can be aware of its abstractive activity in relation to individual human knowers. This lack of awareness on the part of the agent intellect is not a function of its being the agent of abstraction per se, however, but rather of the characteristics of separateness and immateriality that are required by its status as a fully actual intellect. Since these characteristics are not present in the case of the cogitative faculty, as we have already noted, it will also be possible to admit that an abstractive internal sense faculty does have some awareness of the intentions and images that it is combining, even if it is only through the faculty of memory itself that the individual intention is fully grasped as a distinct object from the image. 65

In fact, Averroes's remarks on the scale of sensible abstraction are most naturally interpreted in just such a fashion. Since the images received by the senses must transmit the "fruit" of the sensible object as well as its "rinds," there must be a sense in which all of the internal senses inchoately possess the intention that becomes fully apprehended only in memory. While it is true that, in Averroes's account, the universal is likewise potentially present in the particular image from which the agent intellect abstracts it, such an image is not actually a universal intelligible in the way in which an individual color, sound, or motion is already actually individual. Thus, Averroes can argue in his discussion of incidental perception in the Great Commentary on the "De anima" that the "comprehension of the individual intention is not [proper to the common sense], although it is an action of the common sense." 66 For in his view of sensible abstraction, the intention is present in every common and proper sensible, and for that reason the cogitative faculty is able to separate it without radically transforming its nature in the way in which the intellect must transform the nature of the image to make it a universal intelligible. To this extent, the cogitative faculty, like the other internal senses, must in some sense contain the images and intentions that

65. The claim that a faculty can be compositive of images without actually perceiving them is explicitly upheld by one of Avicenna's commentators, Nașr al-Dīn al-T ùīi (d. 1274). In his commentary on the Ishärat wa-Tanbihät (Directives and Remarks), $T \bar{u}$ ūi ( argues that Avicennian compositive imagination (al-takhayyul) is a faculty that "has free disposal (tașarruf) over two things whose presence it does not perceive." For TT üsi's commentary, see the anonymous edition of Avicenna's Ishärät wa-Tanbihāt, 3 vols., 2nd ed., (Tehran: Daftar Nashr Kitab, 1983), vol. 2, p. 45.

66. GCDA 2.65, p. 228.32-34. 
it combines and divides. But in the strictest and most proper sense, the understanding and awareness of an intention in its own right belongs to the memory alone, as a receptive faculty for the purified intention.

\section{TIME AND INDIVIDUALITY: INTERPRETING THE SPIRITUALITY OF MEMORY}

In concluding my examination of Averroes's view of the memorative faculty, I would like to address the philosophical implications of his transformation of memory from a faculty that is aware of past perceptions to one that is perceptive of the individual as individual. In particular, I wish to consider the question of whether Averroes is justified in claiming that memory is the most abstract of the sensible faculties in virtue of the fact that it is assigned the function of grasping the purified individual intention. Does Averroes adequately explain how or why the "fruit" that is the individual intention should be such as to render the faculty that receives it the summit of the sensible soul's abstractive powers?

Answering this question is not an easy matter, however, principally because of Averroes's ultimate failure both to define the technical notion of an intention and to articulate how the grasping of such intentions is tied to what we usually think of as memory-activities. It is clear that Averroes links the intention with the two related properties of being an individual (shakhs) and being denotable, a "this something" in Aristotle's terms. While the most obvious example of such an intention would be an individual substantial form, the Great Commentary on the "De anima" explicitly allows for "intentions of each of the ten individual predicaments." 67 This wider notion of an intention is also presupposed a few comments later, when Averroes remarks that we usually need to rely on the perception of a variety of sensible forms in order to grasp the intention that underlies them: "And therefore it is often necessary, in understanding the individual intention, to use more than one sense, just as doctors, in order to learn whether someone suffering from a paroxysm of the veins is alive, use more than one sense."68 Thus intentions include accidental qualities that accrue to the whole individual, such as the state of being alive or dead, as well as its individuality as such.

Indeed, in the Great Commentary on the "De anima" Averroes generally invokes intentions in the context of explaining Aristotle's concept of inci-

67. GCDA 2.63, p. 225.44-50.

68. GCDA 2.65, p. 228.34-37. Cf. EDA, p. 27: "As for the incidental sensibles, such as sensing that this is dead and that is alive, and that this is Zayd and that is 'Umar, error [occurs] in these sensibles more than in the common sensibles. And for this reason, it is necessary, in discerning them, to use more than one sense, just as doctors do in the case of someone with a paroxysm of the veins. For they may bleed him sometimes; and sometimes they may put a mirror up to his nose, so that the traces of his breathing are made visible in it for them." 
dental perception. 69 Thus, Averroist intentions serve the role of specifying just what an incidental percept is over and above the object's common and proper sensible forms on which the incidental perception supervenes. And this seems to explain in part their link to the notion of memory. The simple act of retaining a prior sensible perception is common to both memory and imagination; what is peculiar to memory is the recognition that some sensible property belongs to a specific and identifiable individual object. Thus my possession of an image of the color purple or the scent of jasmine is simply an act of imagination; but if I recall this particular shade of purple or that particular jasmine perfume, memory must be supplying an intention as well. The intention may often include an awareness of the occasion on which this individual perception occurred-hence the normal association of memory with the past-but it need not do so, as in cases of creative imagination. ${ }^{70}$ Therefore, although the intention itself need not be of a substance, as in Averroes's own example of "life," it does seem to be the case that to perceive an intention presupposes the implicit assignment of the intentional property grasped to an individual substance of some kind, whether determinate and real (like "Zayd" or "Diares' son") or fictional. Once an intention is involved, the associated images are no longer random instances of properties but the properties of some particular thing. ${ }^{71}$

So it remains the case that intentions will always be radically individual in a way that no sensible form taken in isolation can be. Indeed it is the individuality of intentions that prevents them from being viewed as proper or common-rather than incidental-sensibles, because if the grasp of intentions were a function of sensation as such, Averroes argues, this would limit each external sense to perceiving its proper sensible as the property of some particular individual: "Vision is not affected by the incidental sensible intention; because if it were affected by some individual insofar as it is that individual, it could not be affected by any other individual."72 So if vision in itself perceived not merely "red" but rather "this red apple" or "that red book," it would be unable to perceive the red color of any other thing. ${ }^{73}$ Individuality as such, then, exceeds the perceptual abilities of the senses and imagination as much as do universality and immateriality; hence even the sensible grasp of the individual requires a special faculty dedicated to this task.

69. This has already been noted by Blaustein, Averroes on Imagination and Intellect, pp. 80-81.

70. It could also be argued that pastness is one of the accidental intentions, as Aquinas does in ST 1.78.4: "Et ipsa ratio praeteriti quam attendit memoria, inter huiusmodi intentiones computatur."

71. Although again, Averroes never makes such a point explicitly, it seems implicit in his account; moreover, it seems a natural extension of Aristotle's phantasma-eikon contrast.

72. GCDA 2.65, pp. 228.53-229.55.

73. This is reminiscent of certain standard arguments pertaining to the problem of universals; for example, if the universal were essentially identical with any one of its instances, it could not also be common to the remaining instances. 
But can Averroes's claims for memory, based on its capacity to apprehend the individual intention, be reconciled with his commitment to the metaphysical view that matter, which is in itself opaque to the intellect, is the principle of individuation? ${ }^{74}$ In such a view of individuation, it is difficult to see how the memorative faculty's grasp of the intention could consistently serve as the basis for its claim to be the most spiritual and abstract of the sensible soul's faculties - that is, the faculty that most closely approximates the character of intellectual apprehension. One does not need to look far for texts in the Averroist corpus that uphold the view that individuating matter is what separates the sensible powers of the human soul from its abstract intellectual powers: "And the difference between rational conception and imaginative conception ... is that we only conceive of things that are imagined insofar as they are individual and material,"75 and again,

It is evident from the nature of the existence of the forms of intelligibles in humans that their existence in them is different from the existence of the rest of the forms of the soul in them, because the existence of these other forms in their ostensible subject (fi mawd $\bar{u}^{\prime}-h \bar{a}$ al-mushärilay-hi) is not [the same as] their intelligible existence, and this is because [an intelligible form] is one insofar as it is intelligible, and many insofar as it is an individual existent in matter. ${ }^{76}$

There appears to be no way around Averroes's claim that it is through the individuating role of matter that the entire sensible realm is separated from the intelligible and that precisely because of its independence from such individuating matter, intellectual cognition alone can be called "abstract" in the fullest sense of the term. At best, "abstraction" is predicated equivocally of the operations of the internal sense faculties. And as far as the cognitive object itself is concerned, Averroes has no explanation of why an individual intention, if known as individual, will not remain radically material and

74. For a consideration of Averroes's views on individuation along with those of Avicenna, see Allan Bäck, "The Islamic Background: Avicenna (B. 980; D. 1037) and Averroes (B. 1126; D. 1198)," in Individuation in Scholasticism: The Later Middle Ages and the Counter-Reformation 1150-1650, ed. J. J. E. Gracia (Albany: SUNY Press, 1994), pp. 39-67.

75. Averroes is using "imagination" as a generic term for all of the internal senses here, as is clear from his allusion in the next sentence to the "four grades of individual intention."

76. EDA, pp. 61, 75; cf, pp. 67-68: "This is something that is evident from what has been said in many places, that apprehended intentions are of two types, either universal or particular, and that these two types of intentions are ultimately different. And this is because the universal is the perception of the general intention abstracted from matter, and the individual perception is the perception of the intention in matter .... And in general we cannot imagine sensibles abstracted from matter, and we only perceive them in matter, this being the respect in which they are individualized." 
dependent on matter for its comprehension. There is no underlying abstract, ontological principle in individual particulars that accounts for their individuality, other than their multiplication by matter; and there are no individual essences or quiddities from which intentions can be derived. Hence, there is ultimately no real basis in the object that could account for Averroes's claim that to perceive an individual as an individual is to perceive something more abstract, and more spiritual, than its physical description.

What, then, is going on in Averroes's account of the spirituality of memory? The most obvious answer is that in attempting to adapt the notion of an "intention"-understood in its Avicennian sense as the nonmaterial accompaniment of a sensible form-to a more strictly Aristotelian framework, Averroes came face to face with the opacity of the individual in Aristotelian metaphysics. ${ }^{77} \mathrm{He}$ recognized that there is some element in the cognition of the individual-not as a random instance of a universal or a random collection of physical properties but as a distinct and integral thing unto itself-that defies explanation in terms of the standard Aristotelian split between the universal and the particular, the intelligible and the sensible, the material and the immaterial. But Averroes had no underlying desire to break down the ontological barriers on which the dichotomy with which he was faced was built; and for that reason, he has no consistent explanation to offer of what it is in the things themselves that memory grasps when it recognizes an individual of any sort in its individuality.

77. By contrast, Avicenna has an explicit argument in support of the abstractness of estimative intentions as he construes them, that is, as properties that are not essentially material in themselves but which the estimation perceives as attached to material individuals. See Al-Najăh, p. 347; Rahman, Avicenna's Psychology, pp. 39-40: "This is because shape, colour, position, \&c., are attributes which cannot be found except in bodily matters, but good and evil, agreeable and disagreeable, \&c., are in themselves non-material entities and their presence in matter is accidental. The proof of their being non-material is this: If it were of their essence to be material, then good and evil, agreeable and disagreeable would be inconceivable except as accidents in a physical body. But sometimes they are conceived in themselves apart from matter. It is clear that in themselves they are non-material and their being in matter is entirely by accident." Cf. Shifa': De anima 2.2, pp. 60-61; Liber de anima, vol. 1 , pp. 118-120. 
